\title{
"OS DESAFIOS DO DIREITO DO SÉCULO XXI", COORDENADA POR MANUEL MONTEIRO GUEDES VALENTE
}

\author{
"THE CHALLENGES OF LAW IN THE 21 ${ }^{\text {ST }}$ CENTURY", \\ COORDINATED BY MANUEL MONTEIRO GUEDES VALENTE \\ EDITORA ALMEDINA, 2018
}

\begin{abstract}
GALILEU - REVISTA DE DIREITO E ECONOMIA - e-ISSN 2184-1845
Volume XIX $\cdot 1^{\text {st }}$ July Julho $-31^{\text {TH }}$ December Dezembro $2018 \cdot$ pp. 160-164

DOI: https://doi.org/10.26619/2184-1845.XIX.2.9
\end{abstract}

O livro é o segundo de uma promissora linha de investigação que seu coordenador, Manuel Monteiro Guedes Valente, vem desenvolvendo no âmbito do Ratio Legis - Centro de I\&D da Universidade Autónoma de Lisboa, trazendo à discussão temas relativos ao Genoma Humano, Europeísmo, Poder e Política, Constituição e Democracia. Compõe-se de nove artigos escritos por autores de Portugal, Espanha, Itália, Moçambique e Brasil, sumariamente assim dispostos: 1) El reglamento de la Fiscalía Europea y su incidencia en los derechos y garantías procesales (un acercamiento desde el ordenamiento jurídico español), por María Ángeles Pérez Marín; 2) Direito, Genoma e Identidade: desafios, por Stela Barbas; 3) O direito genómico hoje: análise do eugenismo e da dignidade humana centrada no pensamento de Habermas, por Virgílio Serra de Carvalho; 4) Il potere giudiziario e la legge processuale penale in Italia, por Bruna Capparelli; 5) Estado, Poder e Segurança, por Eduardo Pereira Correia; 6) A despesa pública justa, por Maria D'Oliveira Martins; 7) O GRPD, ou Regulamento Geral de Proteção de Dados como exemplo da tendência de um Estado fiscalizador do cumprimento de direitos fundamentais, por Pedro
Trovão do Rosário; 8) Fenomenologia quântica da Constituição: proatividade normativa, pulsar da realidade e mutação, por Rodrigo Lobato Oliveira de Souza; e 9) Normatividade e perspectivas supranacionais, por Nereu José Giacomolli.

A diversidade temática do livro, embora possa parecer ao leitor mais desatento um apanhado caótico de questões desconexas, tem na verdade uma unidade discursiva que se pode reconduzir à preocupação comum de seus autores em buscar respostas jurídicas às diversas mutações sociais, políticas e econômicas que se fazem sentir no âmbito da vida jurídica, cujo coração ainda pulsa a partir da ideia de proteção do homem face às múltiplas possibilidades de submissão arbitrária ao poder sem controle. A leitura de cada artigo, nesse sentido, conduz-nos pelo esforço de cada autor para construir um discurso jurídico segundo novas intituições que emergem do enfrentamento do novo, na dimensão fática do direito, mas não necessariamente implicando uma negação da dimensão valorativa que se tem alimentando da ideia de justiça e orientado por esta que constitui a fonte do humanismo jurídico ocidental. O louvável 
na obra está, portanto, em conseguir identificar na mutação da realidade seus novos problemas que confrontam o direito, embora ainda reafirmando a racionalidade jurídica como uma dimensão irrecusável ao homem, mesmo diante dos problemas que surgem na era da sociedade global, comuncacional e científica.

Os desafios do direito do século XXI se tornam, assim, os desafios do "homo juridicus", como o descreve Alain Supiot na busca pela compreensão simbólica do sentido da vida, do homem que se insurge contra o direito posto, mas que do direito ainda depende até para poder continuar insurigindo-se, já não necessariamente contra a ordem jurídica posta, porque em constante mutação, mas contra a nova ordem que se vai constituindo pelas expressões do poder nas diversas esferas da vida do homem, não apenas como cidadão de um Estado, parte num contrato ou sujeito à persecução penal, mas já agora nas novas e diversas esferas que se vão construindo em torno de sua vida, acrescendo-lhe não apenas novas liberdades como também novas constrições aos direitos fundamentais.

É, assim, que se podem identificar novas dimensões de existência e convivência humana, que questionam o direto no século XXI, desafiando-lhe com problemas que emergem no âmbito do espaço europeu e global, a exigir uma recompreensão das relações entre poder legislativo e judicial, no quadro da representatividade democrática; no âmbito do espaço digital, a exigir uma recompreensão dos direitos fundamentais; no âmbito do espaço científico com os avanços da engenharia genética, a exigir um biodireito capaz de salvar a dignidade humana da vontade excessiva de saber que se pode transmudar muito facilmente em uma nova vontade de poder, que nos abrirá não para um novo iluminismo, como o descreve Steven Pinker, mas para uma nova idade média assombrada pelos avanços da tecnologias.

O livro, é certo, não esgota todas as questões jurídicas que têm desafiado o direito do século XXI, mas a considerar que se trata do segundo de uma linha de investigação, esperamos que outros se sigam e persistam desvendando os novos espaços jurídicos, ampliando nossa percepção do direito e nosso crescimento como homem jurídico. É este o contributo da obra que merece ser lida e discutida no espaço da Universidade, para a qual devem convergir as questões que interessam ao homem do século XXI.

\section{ELIOMAR DA SILVA PEREIRA}

Doutor em Direito pela Universidade Católica Portuguesa

Professor e Coordenador do Programa de Pós-Graduação da Escola Superior de Polícia (Polícia Federal do Brasil) 